\title{
New Enzymes with Potential for PET Surface Modification
}

\author{
GUDRUN FISCHER-COLBRIE ${ }^{\mathrm{a}}$, SONJA HEUMANN ${ }^{\mathrm{b}}$, STEFAN LIEBMINGER ${ }^{\mathrm{b}}$, EVA ALMANSA $^{\mathrm{a}}$, \\ ARTUR CAVACO-PAULO ${ }^{\mathrm{c}}$ and GEORG M. GUEBITZ ${ }^{\mathrm{b} *}$ \\ ${ }^{a}$ Applied Biocatalysis Research Centre, Petersgasse 14, A-8010 Graz, Austria; ${ }^{b}$ Graz University of Technology, Dept. of Environmental Biotechnology, \\ Petersgasse 12, A-8010 Graz, Austria; ' ${ }^{\circ}$ University of Minho, Dept. of Textile Engineering, 4800 Guimaraes, Portugal
}

This work describes newly isolated organisms and their potential to modify the surface of polyethylene terephthalate (PET). Out of the different screening processes, four bacterial and five fungal strains were isolated. A PET model substrate was synthesized (bis (benzoyloxyethyl) terephthalate) and used in the screening process, mimicking the polymer in its crucial properties and having the advantage of defined hydrolysis products. On this model substrate, extracellular enzyme preparations from the isolated microorganisms showed a maximum activity of $8.54 \mathrm{nkat} / \mathrm{L}$. All enzyme preparations showed esterase activity on $p$-nitrophenyl-acetate while no activity was found on $p$-nitrophenyl decanoate or $p$-nitrophenyl palmitate. Increased hydrophilicity of PET fabrics after enzyme treatment was found based on rising height and water dissipation measurements.

Keywords: Polyethylene terephthalate; PET model substrate; Bis (benzoyloxyethyl) terephthalate; Drop dissipation; Rising height

\section{INTRODUCTION}

Polyethylene terephthalate (PET) is the most important polymer used for the production of synthetic textile fibres. In 2002, the worldwide production of synthetic fibres was 33.6 million tons, which is a market share of $55 \%$ of the total textile market. Within the group of synthetic fibres, total PET production was 21.0 million tons, accounting for a $38 \%$ share (Engelhardt, 2003). However, not only is the demand for PET textile fibres increasing, but also the desire for improved textile properties such as wettability or hydrophilicity. Furthermore, effects like better dyeability with water soluble dyes or surface functionalisation for special purposes like coupling of flame retardants are desirable from the perspective of the textile industry. Besides textiles, enzymatic modification of synthetic materials has immense potential for speciality applications such as in medical devices and electronics (Ritter, 1997; Yoon et al., 2002).

In recent years, there have been major research efforts to find technologies that can meet these demands. Two technologies suitable for this purpose have been identified, which are plasma technology on the one hand, and enzymatic technologies on the other hand (Grace and Gerenser, 2003; Gübitz and Cavaco-Paulo, 2003). Both innovative technologies show the advantage of lower energy consumption and avoid the use of harsh chemicals, when compared to a chemical surface treatment.

Enzymes have been used for the improvement of the properties of natural polymers such as polysaccharides and lignocellulose materials for many years (Gübitz and Cavaco-Paulo, 2003). Obviously, such enzymes have been isolated from microorganisms which are responsible for the decomposition of these natural polymers in the environment. Although such an approach is not possible for synthetic polymers, the potential of enzymes for their modification has recently been reported. Nitrilases have been employed for hydrolysis of nitrile groups and polyacrylonitrile (Battistel et al., 2001; Tauber et al., 2000) while oxidative enzymes have shown potential for the modification of polyamide fibres (Deguchi et al., 1998; Miettinen-Oinonen et al., 2002).

Potentially a great variety of enzymes could be used to modify the surface of PET: Amongst the hydrolytic enzymes, besides esterases and lipases, enzymes acting on natural polyesters such as cutinases or polyhydroxyalkanoate depolymerases could have potential (Braaz et al., 2003; Calado et al., 2004). However, there are a number of reports on the hydrolysis on synthetic aliphatic polyesters while aromatic polyesters seem to be more recalcitrant to

\footnotetext{
* Corresponding author. E-mail: guebitz@ima.tu-graz.ac.at
} 
microbial/enzymatic attack (Muller et al., 2001; Walter et al., 1995).

Previously, treatment of PET with lipases has been shown to improve wetting and absorbency of PET fabrics while strength was retained (Xie and Hsieh, 2003). Compared to chemical hydrolysis by alkali treatment, enzymatic surface hydrolysis has the advantage of maintaining mechanical stability, because the enzyme cannot penetrate into the fibre and is therefore restricted to reacting on the very surface only. Improved stain resistance, wettability and/or dyeability of PET fabrics treated was reported with so-called polyesterases (lipases, esterases or cutinases) (Yoon et al., 2002). Pilling properties of polyester fabrics were found to be improved by treatment with enzyme preparations from Humicola sp. Candida sp. and Pseudomonas sp. (Andersen et al. , 1999). In these studies, existing enzymes were used chosen based on their natural role to hydrolyse ester bonds in lipids and polyesters.

Oxidative enzymes, such as laccases, have also been shown to hydrophilize the PET surface (Miettinen-Oinonen et al., 2002). Although oxidative modification with laccases would be especially interesting since functionalization could be achieved without cleavage of the polymer, there is no detailed mechanistic or application related data available yet.

Although promising results in modification of PET with some existing enzymes have been obtained, new more efficient enzymes are needed to allow industrial application of this technology. In this paper, we focus on the isolation of enzymes from new microbial sources screened for the capability of PET surface modification.

\section{MATERIALS AND METHODS}

\section{Screening for Microorganisms and Culture Conditions}

In order to find new microorganisms with potential enzymes to modify the surface of PET, a screen was carried out (Fig. 1). Soil samples from different landfills in the surroundings of Graz, Austria and samples from a sewage composting plant (Hartberg,
Austria) served as inoculum. The purpose of the screen was to find microorganisms with the ability to metabolize polyethylene terephthalate (PET) as their only carbon source. Microorganisms with this potential are likely to produce enzymes which can modify the water insoluble polymer chain. The screening was carried out using a mineral salt medium consisting of $\mathrm{KH}_{2} \mathrm{PO}_{4}\left(2.5 \mathrm{~g} \mathrm{~L}^{-1}\right), \mathrm{K}_{2} \mathrm{HPO}_{4}$ $\left(3 \mathrm{~g} \mathrm{~L}^{-1}\right), \mathrm{NH}_{4} \mathrm{Cl}\left(2 \mathrm{~g} \mathrm{~L}^{-1}\right), \mathrm{MgSO}_{4} \cdot 7 \mathrm{H}_{2} \mathrm{O}\left(0.2 \mathrm{~g} \mathrm{~L}^{-1}\right)$ in tap water. $5 \mathrm{~mL} \mathrm{~L}^{-1}$ of a trace element solution according to Stelkes-Ritter (Stelkes-Ritter et al., 1995) were added and the $\mathrm{pH}$ was adjusted to 7.0. All chemicals were p.a. grade and obtained from Merck (Darmstadt, Germany). PET polymer powder (10 $\mathrm{g} \mathrm{L}^{-1}$; Type $\left.74 \mathrm{A00}, 200-500 \mu \mathrm{m}\right)$ obtained from Rhodia Industrial Yarns (Emmenbrücke, Switzerland) was added to the medium. $250 \mathrm{~mL}$ Erlenmeyer flasks containing $100 \mathrm{~mL}$ PET-solution were inoculated with $10 \mathrm{~g}$ of soil sample. Incubation conditions were $30^{\circ} \mathrm{C}$, $60 \%$ humidity and $124 \mathrm{rpm}$ on a reciprocal shaker. After 3 weeks, samples were taken and transferred to rich medium agar plates (Standard I nutrient agar, Merck Darmstadt, Germany). Individual organisms growing on these plates were isolated on rich medium agar plates and subsequently pure strains were retransferred to a PET containing medium. Additionally, pure cultures were transferred to media containing a PET model substrate $\left(10 \mathrm{~g} \mathrm{~L}^{-1}\right.$, Fig. 2).

Cultures with the ability to grow on the polymer or on the corresponding model substrate were stored at $+4^{\circ} \mathrm{C}$ on PET agar plates (liquid medium as described above with $15 \mathrm{~g} \mathrm{~L}^{-1}$ agar-agar).

Another screening process for fungi was carried out with a PET model substrate as the only carbon source and the mineral salt medium at pH 5 . Medium components and culture conditions were exactly the same with the exception of $\mathrm{KH}_{2} \mathrm{PO}_{4}$ $\left(2.5 \mathrm{~g} \mathrm{~L}^{-1}\right)$ and $\mathrm{K}_{2} \mathrm{HPO}_{4}\left(3 \mathrm{~g} \mathrm{~L}^{-1}\right)$, which were replaced by $\mathrm{KH}_{2} \mathrm{PO}_{4}\left(5 \mathrm{~g} \mathrm{~L}^{-1}\right)$. Due to the lower $\mathrm{pH}$ value, fungal strains have been selected following this method. Fungal cultures obtained were stored on potato dextrose agar plates (PDA Agar, ready mixture, Fluka Chemie, Buchs, Switzerland).

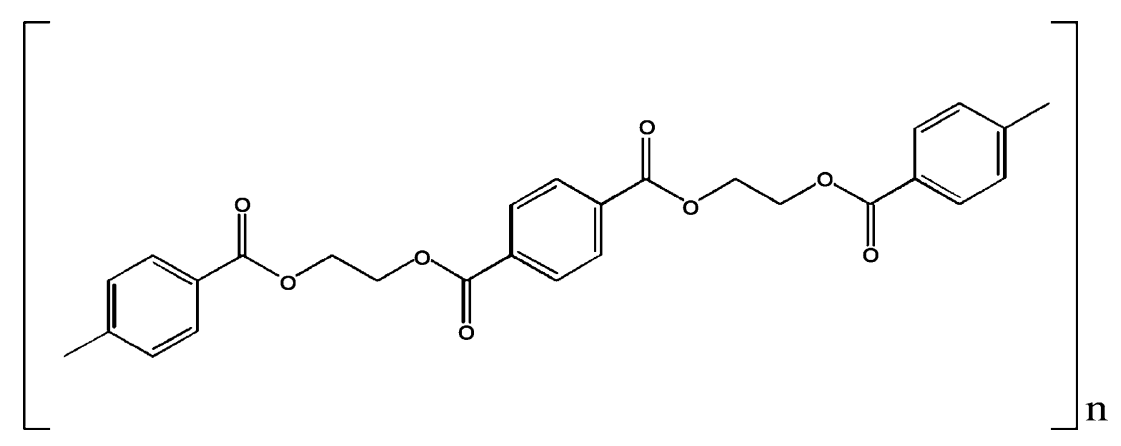

FIGURE 1 Molecular structure of poly(ethylene terephthalate) PET. 
<smiles>O=C(OCCOC(=O)c1ccc(C(=O)OCCOC(=O)c2ccccc2)cc1)c1ccccc1</smiles>

FIGURE 2 Molecular structure of the model substrate for polyester: bis (benzoyloxyethyl) terephthalate.

\section{Synthesis of the Model Substrate}

Synthesis of the PET model substrate bis (benzoyloxyethyl) terephthalate was carried out in two steps according to a method modified from Allan et al . (1957) (see also Fig. 3). In a first step, benzoylchloride (99\%, Acros Organics, Geel, Belgium) and a 1.2 fold excess of 2-chloroethanol (99\%, Sigma-Aldrich Chemie, Germany) were mixed and stirred at $110^{\circ} \mathrm{C}$ for $24 \mathrm{~h}$ to form the benzoic acid 2-chloroethylester. The excess of 2-chloroethanol was removed under reduced pressure on a rotavapor ${ }^{\circledR}$ (Büchi, Flawil, Switzerland). The second step was the esterification of terephthalic acid (for synthesis, Merck-Schuchardt, Darmstadt, Germany) with 2-chloroethylbenzoate. For this purpose, $1 \mathrm{~mol}$ terephthalic acid per 2 mol benzoic acid 2-chloroethylester (calculated on the theoretical yield of $100 \%$ ) was dissolved in dimethylformamide (Riedel-de $\mathrm{Haen}^{\circledR}, \quad 99+\%$, Sigma-Aldrich Chemie) and this solution was added to the reaction mixture of the first reaction step. An amount of triethylamine (Riedel-de Haen ${ }^{\circledR}, 99+\%$, Sigma-Aldrich Chemie) equimolar to the resulting $\mathrm{HCl}$ was added to the mixture. The esterification was carried out at $140^{\circ} \mathrm{C}$ for $24 \mathrm{~h}$. After cooling the reaction mixture to room temperature, the triethyla- mine hydrochloride was removed from the mixture by filtration. The solvent dimethylformamide was removed under reduced pressure on a rotavapor ${ }^{\circledR}$, and the residue was suspended in toluene (purum $99+\%$, Fluka Chemie). The excess of terephthalic acid remained insoluble and was removed from the mixture by filtration. The toluene solution was dried under vacuum and the resulting product was recrystallised from methanol (99+\%, Sigma-Aldrich Chemie). This product was further purified on a silica gel column with a toluene/acetic acid ethyl ester (for synthesis, 99+\%, Carl Roth) 5/1 (v/v) mixture. Structure and purity of the product were confirmed with NMR and MS. NMR spectra were recorded on a Varian Unity Inova 500 instrument; ${ }^{1} \mathrm{H}$ and ${ }^{13} \mathrm{C}$ data were measured at $499.8 \mathrm{MHz}$ and 125.7 MHz, respectively. Mass spectra were recorded on a double-focussing Kratos Profile mass spectrometer with electron-impact ionization (EI: $70 \mathrm{eV}$ ). Samples were introduced directly by insertion.

\section{Esterase Assay and Protein Content}

Esterase activity was measured using 4-nitrophenyl acetate as a substrate. The method used was modified from Murphy et al. (1996). $84 \mu \mathrm{g}$ of 4- nitrophenyl<smiles>O=C(Cl)c1cccc(C(=O)OCCCl)c1</smiles><smiles>O=C(O)c1ccc(C(=O)OCCCl)cc1</smiles><smiles>O=C(OCCOC(=O)c1ccc(C(=O)OCCOC(=O)c2ccccc2)cc1)c1ccccc1</smiles>

FIGURE 3 Reaction scheme of the synthesis of the PET model substrate bis (benzoyloxyethyl) terephthalate. 
acetate (97\%, Acros Organics) were dissolved in $1000 \mu \mathrm{L}$ DMSO (extra pure, Merck) and stored at $-20^{\circ} \mathrm{C}$ until use. The assay mixture consisted of $1 \mathrm{~mL}$ of a $100 \mathrm{mmol} \mathrm{L}^{-1}$ Tris* $\mathrm{HCl}$ buffer at $\mathrm{pH} 7$ (resp. pH 5.5, when fungal enzymes were assayed), $100 \mu \mathrm{L}$ of culture supernatant (obtained by filtration of a fermentation sample through a filter with $0.45 \mu \mathrm{m}$ pore size) and $10 \mu \mathrm{L}$ of the substrate solution. This mixture was allowed to incubate for $3 \mathrm{~min}$ at room temperature before the increase of the absorbance at $405 \mathrm{~nm}$ was measured at room temperature using a Hitachi U 2001 spectrophotometer. A blank was measured using $100 \mu \mathrm{L}$ buffer instead of sample. The increase of the absorbance at $405 \mathrm{~nm}$ indicates an increase of 4-nitrophenolate due to hydrolysis of the substrate. The activity was calculated in nkat, where 1 nkat is the amount of enzyme required to hydrolyze $1 \mathrm{nmol}$ of substrate per second under the given $\mathrm{pH}$ and temperature conditions.

The protein content in enzyme preparations was measured according to the Lowry method (Lowry et al., 1951).

\section{Determination of the Enzyme Activity on the PET Model Substrate}

$1 \mathrm{~mL}$ sample was inoculated on an excess of bis (benzoyloxyethyl) terephthalate for $24 \mathrm{~h}$ on a thermomixer ${ }^{\circledR}$ (Eppendorf, Hamburg, Germany) at $30^{\circ} \mathrm{C}$ and $1400 \mathrm{rpm}$. The reaction was stopped by adding $50 \mu \mathrm{L}$ concentrated $\mathrm{H}_{2} \mathrm{SO}_{4}$. The precipitated protein and the substrate were removed from the mixture by centrifugation at $9500 \mathrm{~g}$ for $10 \mathrm{~min} .500 \mu \mathrm{L}$ of the substrate were extracted with the same volume of a toluene/acetic acid ethyl ester mixture $5 / 1(\mathrm{v} / \mathrm{v})$ by shaking vigorously for $5 \mathrm{~min}$. The organic phase was applied on a silica TLC card with fluorescent indicator at $254 \mathrm{~nm}$ (Fluka Chemie) and the TLC was run with a toluene/acetic acid ethyl ester mixture $5 / 1(\mathrm{v} / \mathrm{v})$.

The residual aqueous phase was used for high performance liquid chromatography (HPLC) analysis. Benzoic acid resulting from hydrolysis of bis (benzoyloxyethyl) terephthalate was determined using a reverse-phase C18 column (Hypersil ${ }^{\circledR}$ ODS

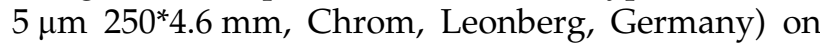
a Dionex HPLC with a photodiode array detector type Dionex PDA 100. Samples were eluted with $8.5 \mathrm{mmol} \mathrm{L}^{-1} \mathrm{H}_{3} \mathrm{PO}_{4}$ (Rotipuran ${ }^{\circledR}$ p.a., Carl Roth, Karlsruhe, Germany, diluted with bideionised water) and detected at $228 \mathrm{~nm}$.

\section{Enzymatic Treatment of the Fabrics}

Fabrics used were obtained from InoTEX (Dvur Kralove, Czech Republic. Characteristics: plain weave, warp and weft: $167 \mathrm{dtex}, 192 \mathrm{~g} \mathrm{~m}^{-2}$ ). Prior to enzymatic treatment, fabrics were washed with an aqueous sodium phosphate solution $\left(1.5 \mathrm{~g} \mathrm{~L}^{-1}\right.$, sodium phosphate p.a. grade, Merck, dissolved in demineralised tap water) at $80^{\circ} \mathrm{C}$ for $30 \mathrm{~min}$ and dried overnight in order to remove finishing agents. The enzymatic treatment was carried out at $20^{\circ} \mathrm{C}$ applying the enzyme preparation $(5 \mathrm{~mL}$ per $50 \mathrm{~mL}$ ) in $50 \mathrm{mM}$ citrate buffer $\mathrm{pH} 6.4$ for $2 \mathrm{~h}$, using a reciprocal shaker at $50 \mathrm{rpm}$ for agitation. The same amount of denaturated enzyme preparation was applied on the fibre as a sample blank. After treatment, the fabrics were washed once with a sodium carbonate solution (Merck, p.a. grade, $25 \mathrm{mM}$ in double distilled water) and twice with demineralised tap water, each run for $30 \mathrm{~min}$ at room temperature. Prior to using the treated textiles for drop test and rising height measurements, the textiles were dried at room temperature overnight. Fabrics treated with buffer only served as blanks for the drop test and rising height measurements.

\section{Rising Height Measurement and Drop Test}

The water absorption of fabrics was determined using the rising height and drop tests. Rising height was measured using a method slightly modified from DIN 53924. Textile pieces of $2 \times 22 \mathrm{~cm}$ size were applied for measurement, and the rising height of the textile was measured after $10 \mathrm{~min}$. The drop dissipation measurement was carried out according to AATCC specifications ( $\mathrm{Li}$ and Hardin, 1998).

\section{RESULTS AND DISCUSSION}

\section{Screening and Strain Properties}

Bis (benzoyloxyethyl) terephthalate was synthesized (structure and purity confirmed by NMR and MS) as a model substrate for PET which is similar not only in terms of chemical composition but like PET is also insoluble in water. Out of the different screening processes we were able to isolate 4 different bacterial and 5 different fungal strains (Table I). All strains capable of PET degradation were isolated from a mixed culture enriched from soil samples of different landfills. Although there are numerous reports on microbial and/or enzymatic degradation of natural and synthetic aliphatic polyesters, little information is available on the degradation of aromatic polyesters (Braaz et al., 2003; Calado et al., 2004; Muller et al., 2001). Previously, several bacteria have been found to be able to degrade aliphatic/aromatic copolyesters from 1,4-butanediol, adipic acid and terephthalic acid (Witt et al., 1997). However, to the best of our knowledge, no microorganisms have previously been identified which degrade PET. In general aromatic polyesters seem to be quite resistant to enzymatic degradation except 
TABLE I Microorganisms isolated with potential for PET modification

\begin{tabular}{|c|c|c|}
\hline Name & Description & Growth media \\
\hline PA 1 & $\begin{array}{l}\text { Yellow colonies, gram } \\
\text { positive rods }\end{array}$ & $\begin{array}{l}\text { Adipic acid } \\
\text { bishexylamine, cutin }\end{array}$ \\
\hline PA 3 & $\begin{array}{l}\text { Orange colonies, gram } \\
\text { positive rods }\end{array}$ & \\
\hline PA 10 & $\begin{array}{l}\text { Yellow colonies, gram } \\
\text { positive rods }\end{array}$ & $\begin{array}{l}\text { Adipic acid } \\
\text { bishexylamine }\end{array}$ \\
\hline PA 14 & $\begin{array}{l}\text { Dark orange colonies, } \\
\text { gram variable long thin } \\
\text { rods, spore forming }\end{array}$ & \\
\hline St 1a & $\begin{array}{l}\text { Aspergillus sp., white, } \\
\text { green pigmented }\end{array}$ & $\begin{array}{l}\text { PET model substrate, } \\
\text { cutin from apple, fruit } \\
\text { waxes }\end{array}$ \\
\hline St 2 & $\begin{array}{l}\text { Aspergillus sp., green- } \\
\text { brown }\end{array}$ & \\
\hline St 3 & $\begin{array}{l}\text { Aspergillus sp., white- } \\
\text { yellow }\end{array}$ & \\
\hline St 4 & Aspergillus sp., brown & \\
\hline St 5 & Aspergillus sp., white & \\
\hline
\end{tabular}

for polyesters with very long dihydroxylic components (Kawai, 1996; Muller et al., 2001).

Since growth on the PET model substrate was extremely slow, alternative inducing subtrates were tested. All of the fungi and two bacterial strains grew on cutin as the sole carbon source inducing esterase activity. Similarly, adipic acid bishexylamide was used to induce PET degrading enzymes. Polyesters based on adipic acid, 1,4-butanediol and terephthalic acid have previously been used for the induction of enzymes active on polyesters constituted of these molecules (Gouda et al., 2002). Interestingly, when grown on adipic acid bishexylamide as the only carbon source, the extracellular protein fractions of all of the bacterial strains (PA 1, PA 3, PA 10 and PA 14) hydrolysed the PET model substrate in addition to adipic acid bishexylamide (Table II). None of these enzyme preparations attacked the monomeric substrates acetamide and acetanilide. When grown on a rich medium containing peptone, yeast extract and glucose, all of the strains showed only weak esterase activity on $p$-nitrophenyl acetate, and no activity towards the PET model substrate. This indicates that the enzymes needed for hydro- lysis of the insoluble substrates can also be induced by adipic acid bishexylamide. In agreement with these results, other authors have reported that Thermomonospora fusca only produced a hydrolase cleaving an aliphatic-aromatic polyester in the presence of this polymer or of oligomeric fragments (Gouda et al., 2002).

All of the bacterial strains and some of the fungal strains isolated in this study showed esterase activity towards $p$-nitrophenyl acetate and the PET model substrate bis (benzoyloxyethyl) terephthalate in their extracellular protein fraction. Table II summarizes the enzyme activities towards the different substrates which have been tested. Although there are no scientific reports on PET degrading enzymes, there is some indication that lipases and cutinases might be able to cleave ester bonds in PET. Previously, a lipase from a Pseudomonas sp. and a hydrolase from Thermomonospora fusca, which might be a cutinase, have been reported to hydrolyse dibutylterephthalate (Marten et al., 2003). The same authors found no activity on dibutylterephthalate with a number of other lipases and two proteases. The fact that none of the extracellular enzymes from the microorganisms isolated in this study were able to hydrolyse $p$-nitrophenyl decanoate or $p$-nitrophenyl palmitate discounts the possibility that lipases could be responsible for the hydrolysis of PET and the PET model substrate. However, good growth and enzyme induction by cutin with most of the strains indicates that the enzymes responsible might be cutinases. The fungal strains showed the highest esterase activity when grown on cutin from apple peel or on the PET model substrate bis (benzoyloxyethyl) terephthalate. Cutin is known to be an inducer for cutinase activity (Fett et al., 1998). However, extensive research on cutinases in the past has focused on biotransformation of soluble molecules (Carvalho et al. , 1998, 1999) rather than of their specifities on polymers such as polycaprolactone (Murphy et al., 1996).

The properties of the enzyme treated fibres were investigated by determining water drop dissipation, a measurement of the hydrophilicity of PET fabrics

TABLE II Extracellular enzyme activities in nkat $\mathrm{mL}^{-1}$ of isolated microorganisms modifying PET after 1-week incubation. The enzyme preparations showed no activity on $p$-nitrophenyl decanoate or on $p$-nitrophenyl palmitate $(-$, no activity)

\begin{tabular}{lccc}
\hline Strain & $p$-Nitrophenyl-acetate & $\begin{array}{c}\text { Bis (benzoyloxyethyl) } \\
\text { terephthalate }\end{array}$ & $\begin{array}{c}\text { Adipic acid } \\
\text { bishexyl-amide }\end{array}$ \\
\hline PA 1 & 0.52 & $8.54 \mathrm{E}-3$ & $3.1 \mathrm{E}-2$ \\
PA 3 & 0.54 & $7.05 \mathrm{E}-3$ & $3.9 \mathrm{E}-2$ \\
PA 10 & 0.23 & $4.36 \mathrm{E}-3$ & $3.1 \mathrm{E}-2$ \\
PA 14 & 0.57 & $1.57 \mathrm{E}-3$ & $0.9 \mathrm{E}-2$ \\
St 1a & $1.4 \mathrm{E}+3$ & - & - \\
St 2 & $1.7 \mathrm{E}+3$ & - & - \\
St 3 & $2.9 \mathrm{E}+3$ & - & - \\
St 4 & $3.1 \mathrm{E}+3$ & $1.04 \mathrm{E}-3$ & - \\
St 5 & $1.9 \mathrm{E}+3$ & - \\
\hline
\end{tabular}


TABLE III Drop dissipation of the enzyme-treated PET-fabrics

\begin{tabular}{llr}
\hline & \multicolumn{2}{c}{ Water dissipation (min) } \\
\cline { 2 - 3 } Enzyme preparation & Enzyme & Control \\
\hline St 2 & $(95 \pm 2)$ & $(>180)$ \\
St 3 & $(75 \pm 3)$ & $(>180)$ \\
St 4 & $(67 \pm 2)$ & $(>180)$ \\
St 5 & $(49 \pm 1)$ & $(>180)$ \\
Untreated fabric & & $(>180)$ \\
\hline
\end{tabular}

(Table III) Changes that are considered as significant are highlighted in bold letters. It can be seen that enzyme preparations of some of the strains caused significant changes to the polymer fibre, even though the fabric was extremely hydrophobic. In parallel, the rising height of fabrics treated with the extracellular enzyme fractions was measured and a maximum increase of $1 \pm 0.25 \mathrm{~cm}$ was obtained (strain 5). Thus, in agreement with recent reports (Xie and Hsieh, 2003; Yoon et al., 2002), water absorbency of PET fabrics was increased. However, detailed comparison, between this literature data and our results in terms of the potential of the individual enzyme preparations is not possible at this stage since data with pure enzyme would be needed.

The results obtained in this study show that promising new microorganisms have been isolated for producing enzymes for PET modification. Future investigations will focus on detailed characterisation of the isolated enzymes to elucidate the enzymatic mechanism of hydrolysis of the insoluble polymer PET.

\section{Acknowledgements}

The authors wish to thank the European Community (project BIOSYNTEX), the SFG, the FFG, the city of Graz, and the province of Styria for the financial support. NMR spectra were kindly recorded by Carina Illaszewicz and Joerg Weber, and MS spectra were measured by Robert Saf.

\section{References}

Allan, R.J.P., Forman, R.L. and Ritchie, P.D. (1957) Studies in Pyrolysis Part 9, J. Chem. Soc. 2107- 2113.

Andersen, B.K., Borch, K., Abo, M. and Damgaard, B. (1999) Method of treating polyester fabrics. US Patent Nr. 5,997,584, $1-20$.

Battistel, E., Morra, M. and Marinetti, M. (2001) Enzymatic surface modification of acrylonitrile fibers, Appl. Surface Sci. 177, $32-$ 41.

Braaz, R., Handrick, R. and Jendrossek, D. (2003) Identification and characterisation of the catalytic triad of the alkaliphilic thermotolerant PHA depolymerase PhaZ7 of Paucimonas lemoignei, FEMS Microbiol. Lett. 224, 107-112.
Calado, C.R.C., Ferreira, B.S., da Fonseca, M.M.R., Cabral, J.M.S. and Fonseca, L.P. (2004) Integration of the production and the purification processes of cutinase secreted by a recombinant Saccharomyces cerevisiae SU50 strain, J. Biotechnol. 109, $147-158$.

Carvalho, C.M.L., Aires-Barros, M.R. and Cabral, J.M.S. (1998) Cutinase structure, function and biocatalytic applications, Electr. J. Biotechnol. 1, 160-173.

Carvalho, C.M.L., Aires-Barros, M.R. and Cabral, J.M.S. (1999) Cutinase: from molecular level to bioprocess development, Biotechnol. Bioeng. 66, 17-34.

Deguchi, T., Kitaoka, Y., Kakezawa, M. and Nishida, T. (1998) Purification and characterization of a nylon-degrading enzyme, Appl. Environ. Microbiol. 64, 1366-1371.

Engelhardt, A. (2003) The Fiber Year 2002, The Saurer Group, Winterthur, Switzerland.

Fett, W.F., Wijey, C., Moreau, R.A. and Osman, S.F. (1998) Production of Cutinase by Thermomonospora fusca, J. Appl. Microbiol. 86, 561- 568 .

Gouda, M.K., Kleeberg, I., Van den Heuvel, J., Müller, R.J. and Deckwer, W.D. (2002) Production of a polyester degrading extracellular hydrolase from Thermomonospora fusca, Biotechnol. Progr. 18, 927-934.

Grace, J.M. and Gerenser, L.J. (2003) Plasma treatment of polymers, J. Dispers. Sci. Technol. 24, 305-341.

Gübitz, G.M. and Cavaco-Paulo, A. (2003) New substrates for reliable enzymes: enzymatic modification of polymers, Curr. Opin. Biotechnol. 14, 577-582.

Kawai, E. (1996) Bacterial degradation of a new polyester, polyethylene glycol-phthalate polyester, J. Env. Polymer Degr. 4, 21-28.

Li, Y.H. and Hardin, I. (1998) Enzymatic scouring of cottonsurfactants, agitation, and selection of enzymes, Textile Chemist and Colorist 30, 23-29.

Lowry, O.H., Rosebrough, N.J., Farr, A.L. and Randall, R.J. (1951) Protein measurement with the Folin phenol reagent, J. Biol. Chem. 193, 265-275.

Marten, E., Muller, R.J. and Deckwer, W.D. (2003) Studies on the enzymatic hydrolysis of polyesters I. Low molecular mass model esters and aliphatic polyesters, Polym. Degrad. Stab. 80, $485-501$.

Miettinen to Oinonen, A., Silvennoinen, M., Nousiainen, P. and Buchert, J. (2002) Modification of synthetic fibres with laccase. Proceedings of The Second International Symposium on Biotechnology in Textile, April 3-6, 2002, Athens, USA, p. 13.

Muller, R.J., Kleeberg, I. and Deckwer, W.D. (2001) Biodegradation of polyesters containing aromatic constituents, J. Biotechnol. 86, 87-95.

Murphy, C.A., Cameron, J.A., Huang, S.J. and Vinopal, R.T. (1996) Fusarium polypropylactone depolymerase is cutinase, Appl Environ. Microbiol. 62, 456- 460.

Ritter, H. (1997) Functionalized polymers via enzymic synthesis, In: Arshady, R., ed, Desk Reference of Functional Polymers (American Chemical Society, Washington), pp. 103-113.

Stelkes-Ritter, U., Wyzgol, K. and Kula, M.R. (1995) Purification and characterization of a newly screened microbial peptide amidase, Appl. Microbiol. Biotechnol. 44, 393-398.

Tauber, M.M., Cavaco-Paulo, A., Robra, K.-H. and Gübitz, G.M. (2000) Nitrile Hydratase and Amidase from Rhodococcus rhodochrous Hydrolyse Acrylic Fibers and Granulates, Appl. Environ. Microbiol. 66, 1634- 1638.

Walter, T., Augusta, J., Muller, R.J., Widdecke, H. and Klein, J. (1995) Enzymatic degradation of a model polyester by lipase from Rhizopus delemar, Enzym. Microb. Technol. 17, 218- 224.

Witt, U., Müller, R.J. and Deckwer, W.D. (1997) Biodegradation behaviour and material properties of aliphatic/aromatic polyesters of commercial importance, J. Environ. Polymer Degr. 5, 81-89.

Xie, J. and Hsieh, Y.L. (2003) Modification of Cellulose Solids by Enzyme Catalysed Transesterification with Vinyl Esters in Anhydrous Organic Solvents, ACS Symp. Ser. 840, 217-230.

Yoon, M.-Y., Kellis, J. and Poulose, A.J. (2002) Enzymatic modification of polyester, AATCC Review 2, 33-36. 